\title{
Experimental study of endothelial progenitor cells labeled with superparamagnetic iron oxide in vitro
}

\author{
MENG-QI WEI $^{1 *}$, DI-DI WEN ${ }^{1 *}$, XIAO-YING WANG ${ }^{2}$, YI HUAN $^{1}$, YONG YANG $^{1}$, \\ JIAN XU ${ }^{1}$, KANG $\mathrm{CHENG}^{3}$ and MIN-WEN ZHENG ${ }^{1}$ \\ ${ }^{1}$ Department of Radiology, Xijing Hospital, Fourth Military Medical University, Xi'an, Shaanxi $710032 ;{ }^{2}$ Department of \\ Ultrasound, The People's Liberation Army No. 323 Hospital, Xi'an, Shaanxi 710054; ${ }^{3}$ Department of Cardiology, \\ Xijing Hospital, Fourth Military Medical University, Xi'an, Shaanxi 710032, P.R. China
}

Received December 5, 2013; Accepted September 12, 2014

DOI: $10.3892 / \mathrm{mmr} .2014 .3122$

\begin{abstract}
Endothelial progenitor cells (EPCs) have an essential role in counteracting risk factor-induced endothelial injury and protecting against the development of vascular injury, such as myocardial infarction. Magnetic resonance imaging (MRI) was reported to be effective in tracking transplanted stem cells following cell-labeling with superparamagnetic iron oxide (SPIO) nanoparticles. SPIO has previously been used to label and track EPCs; however, the safest concentration of SPIO for labeling EPCs on a cellular level has remained to be elucidated. In addition, the optimum number of SPIO-labeled cells required to produce the highest quality magnetic resonance images has not yet been determined. In the present study, EPCs were isolated from the bone marrow of minipigs using density gradient centrifugation. Their biological activity was then studied using flow cytometric analysis. Cells were incubated at different concentrations of SPIO for different durations and then the growth curve, apoptosis, morphology and labeling efficiency of the EPCs were detected using optical and electron microscopy. T2-weighted fast spin-echo (T2WITSE) MRI of the different numbers of SPIO-labeled EPCs $(35 \mu \mathrm{g} / \mathrm{ml})$ were then obtained in axial and sagittal planes. The results of the present study demonstrated that EPCs were efficiently labeled with SPIO, with a labeling efficiency in each group of $\sim 100 \%$ following incubation for $24 \mathrm{~h}$. SPIO was found to be localized in the endosomal
\end{abstract}

Correspondence to: Professor Min-Wen Zheng, Department of Radiology, Xijing Hospital, Fourth Military Medical University, 15 Chang Le Western Road, Xi'an, Shaanxi 710032, P.R. China E-mail: zhengmw2007@163.com

Mr. Kang Cheng, Department of Cardiology, Xijing Hospital, Fourth Military Medical University, 15 Chang Le Western Road, Xi'an, Shaanxi 710032, P.R. China

E-mail: wendidi1216@gmail.com

*Contributed equally

Key words: endothelial progenitor cells, superparamagnetic iron oxide, magnetic resonance imaging, acute myocardial infarction vesicles of EPCs, which was confirmed by electron microscopy. When the concentration of SPIO was $<70 \mu \mathrm{g} / \mathrm{ml}$, no significant differences were observed in cell viability, proliferative capability $(\mathrm{P}>0.05)$ and morphology between labeled and unlabeled EPCs. Furthermore, the T2WITSE signal intensity was significantly decreased in the groups of $5.0 \times 10^{5} / \mathrm{ml}$ and $1.0 \times 10^{5} / \mathrm{ml}$ compared with that of the control $(\mathrm{P}<0.05)$. In conclusion, the results of the present study indicated that $35 \mu \mathrm{g} / \mathrm{ml}$ was the most effective concentration of SPIO to label EPCs in vitro and acquire a high quality MRI. These findings may therefore contribute to the development of a promising novel therapeutic method for the treatment of myocardial infarction following autograft with SPIO-labeled EPCs in vivo.

\section{Introduction}

Endothelial progenitor cells (EPCs) have the ability to differentiate ex vivo into endothelial-phenotyped cells and were initially detected in the peripheral circulation in 1997 via the isolation of cells expressing the CD34 antigen $(1,2)$. EPCs develop into endothelial cells (ECs) during embryogenesis and human hematopoietic stem cytogenesis $(3,4)$. It has also been reported that hemangioblasts were the multipotent precursor cells of EPCs and hematopoietic stem cells (HSCs). EPCs are known to contribute to the growth of vessels and it was reported that they may induce prolonged vascular recovery from ischemia $(5,6)$. In addition, the transplantation of healthy EPCs to compensate for the role of their dysfunctional counterparts demonstrated promising improvements in numerous animal models of ischemic disease (7-9). EPCs may enter into the circulation by detaching from activated or damaged vessels. Studies have reported the number of circulating EPCs was significantly increased under several pathological conditions that involved vascular injury or instability, including myocardial infarction and cancer $(10,11)$. This therefore suggested that circulating EPCs may have provided an endogenous repair mechanism that counteracted the ongoing risk factor-induced endothelial injury and therefore protected against the development of vascular injuries, such as myocardial infarction (10-13). Therefore, the present study hypothesized that changes in circulating levels of EPCs may act as a predictor for the incidence of acute myocardial infarction. 
Due to its low toxicity, superparamagnetic iron oxide (SPIO) nanoparticles coated with bioprobes were developed for highly specific labeling of targeted tumors in tumor examination and treatment (14-17). Magnetic resonance imaging (MRI) was demonstrated to be effective in tracking transplanted stem cells by labeling cells with superparamagnetic iron oxide (SPIO) nanoparticles (18). The present study investigated the intracellular iron content, labeling efficiency and cell viability of SPIO-labeled EPCs as well as analyzed the MRI results in order to set up a theoretical foundation for the application of autograft EPCs in vivo.

\section{Materials and methods}

Cells. The present study was approved by the ethics committee of Xijing Hospital, Fourth Military Medical University (Xi'an, China). EPCs were derived and cultured as previously described (19). In brief, mononuclear cells (MNC) from minipig (the minipig was purchased from the Experimental Animal Center, Forth Military Medical University, Xi'an, China) bone marrow were first isolated using density gradient centrifugation. MNCs were plated on un-coated tissue culture flasks at a density of $1 \times 10^{6} / \mathrm{ml}$ in Dulbecco's modified Eagle's medium (DMEM; HyClone, Thermo Fisher Scientific, Waltham, MA, USA) containing $10 \%$ fetal bovine serum (FBS; HyClone). Non-adherent cells were then collected and plated on culture flasks following four days of culture and the medium was replaced. Following a further $24 \mathrm{~h}$ of culture, non-adherent cells were collected and seeded into culture flasks at a density of $1 \times 10^{6} / \mathrm{ml}$ in DMEM supplemented with $10 \%$ FBS, vascular endothelial growth factor (VEGF; $10 \mathrm{ng} / \mathrm{ml}$; PeproTech EC Ltd, London, UK) and basic fibroblast growth factor (bFGF; $10 \mathrm{ng} / \mathrm{ml}$; PeproTech EC Ltd). Cells were then maintained at $37^{\circ} \mathrm{C}$ and $5 \% \mathrm{CO}_{2}$. Media was observed daily and changed every two to three days.

Fluorescence-activated cell sorting (FACS) analysis. Flow cytometric staining and analyses were performed as previously described (20). In brief, EPCs were resuspended in $100 \mathrm{ml}$ rinsing buffer and incubated with the following monoclonal antibodies: Phycoerythrin (PE)-conjugated mouse anti-human CD31 (1:50), fetal liver kinase (Flk)-1 (1:100) and factor VIII (1:16,000) (Santa Cruz Biotechnology, Inc, Dallas, TX, USA) for $30 \mathrm{~min}$ at room temperature. Following washing with phosphate-buffered saline (PBS; $\mathrm{pH} 7.35$ ), the expression of membranous antigen on the cells was detected using a FACSCalibur ${ }^{\mathrm{TM}}$ flow cytometer (BD Biosciences, San Jose, CA, USA) equipped with the Cell Quest software (BD Biosciences). Flow cytometric data were analyzed using appropriate controls (cat no.: 1-001-A; R\&D Systems, Inc., Minneapolis, MN, USA) with isotype-matched immunoglobulin $\mathrm{G}$ and unstained controls.

SPIO labeling in vitro. Concentrations of SPIO (Bayer Healthcare Pharmaceuticals, Montville, NJ, USA) in cell culture medium were as follows: Group 1, $17.5 \mu \mathrm{g} / \mathrm{ml}$; group 2, $35 \mu \mathrm{g} / \mathrm{ml}$; group 3, $70 \mu \mathrm{g} / \mathrm{ml}$; and group 4, $140 \mu \mathrm{g} / \mathrm{ml}$, the control group consisted of DMEM without SPIOs. EPCs labeled with SPIO were incubated at $37^{\circ} \mathrm{C}$ and $5 \% \mathrm{CO}_{2}$ atmosphere, EPCs were then washed with culture DMEM and subsequently used for in vitro studies. Following incubation for one day, the growth and morphology of EPCs in culture were observed daily.

Cell viability. Following incubation for one week, all EPCs were washed three times with DMEM, trypsinized, counted and then resuspended. Cells from each group (18 wells/group) were initially seeded in un-coated 96 -well plates and cultured in $37^{\circ} \mathrm{C}$ and $5 \% \mathrm{CO}_{2}$. Following incubation for a further $24 \mathrm{~h}$, cells from each group were added to $500 \mu \mathrm{l}$ MTT (Beyotime Institue of Biotechnology, Haimen, China) and assessed using a standard MTT assay for $4 \mathrm{~h}$. Supernatant fluid was then discarded and $150 \mu$ limethylsulfoxide (DMSO) was added to each well for 10 min with agitation. The light absorption of cells was measured using an ELISA reader (iMark; Bio-Rad Laboratories, Inc., Hercules, CA, USA). Finally a MTT bar graph was drawn.

Electron microscopy. In order to detect the iron concentration within EPCs and observe the morphology of EPCs in culture, SPIO-labeled EPCs were grown in a six-well tissue culture plate until they reached $80 \%$ confluence. Following incubation, the medium was removed and the plate was gently washed twice with sterile PBS. Samples were then digested using trypsin, transferred into a tube and centrifuged at $1,500 \mathrm{x} \mathrm{g}$ for $15 \mathrm{~min}$. The supernatant was removed and cells were fixed with $4 \%$ paraformaldehyde and visualized using an electron microscope (IX83; Olympus Corp., Tokyo, Japan).

Magnetic resonance imaging of SPIO-labeled EPCs in vitro. Different concentrations of SPIO-labeled EPC solution (SPIO, $35 \mu \mathrm{g} / \mathrm{ml}$ ) were collected by removing the free SPIO and washed three times with PBS. The EPCs were suspended in $1 \%$ agarose prior to being transferred into $1.5-\mathrm{ml}$ microcentrifuge tubes. Concentrations of SPIO-labeled EPC cells were as follows: Group a, control; group b, 1.0x10 $/ \mathrm{ml}$; group c, $5.0 \times 10^{4} / \mathrm{ml}$; group d, $1.0 \times 10^{5} / \mathrm{ml}$; and group e, $5.0 \times 10^{5} / \mathrm{ml}$. In vitro MRI of the tubes was then conducted.

MRI scans were performed on a clinical 3.0T whole-body MRI system (MAGNETOMTrioTim; Siemens Healthcare, Erlangen, Germany) following $24 \mathrm{~h}$ culture. T2-weighted fast spin-echo (T2WITSE) MRI measurements were initially obtained in axial and sagittal planes. Imaging parameters for these images were: Repetition time/echo time, $2652110 \mathrm{~ms}$; flip angle, $90^{\circ}$; field of view, $210 \mathrm{~mm}$; slice thickness, $3 \mathrm{~mm}$; matrix size, $205 \times 256$.

Statistical analysis. Statistical analysis was performed using SPSS (version 13.0; SPSS Inc., Chicago, IL, USA). Values are expressed as the mean \pm standard deviation and analyzed using the one-way analysis of variance. $\mathrm{P}<0.05$ was considered to indicate a statistically significant difference between values.

\section{Results}

FACS analysis confirms the identity of EPCs. A large number of molecular markers were reported to be associated with EPCs (21-23); in the present study, several of these molecular markers were detected using flow cytometry in order to identify EPCs. The results of the FACS analysis revealed EPCs were positive for the markers CD31, Flk-1 and factor VIII in 


\section{CD31}

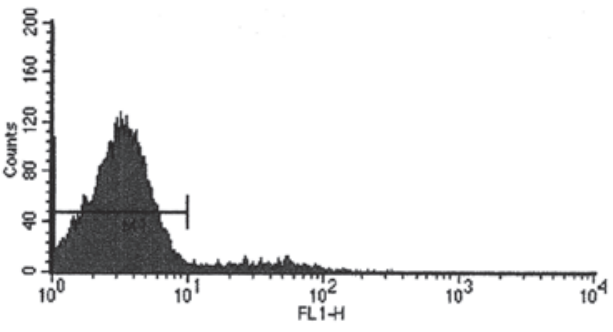

Flk-1

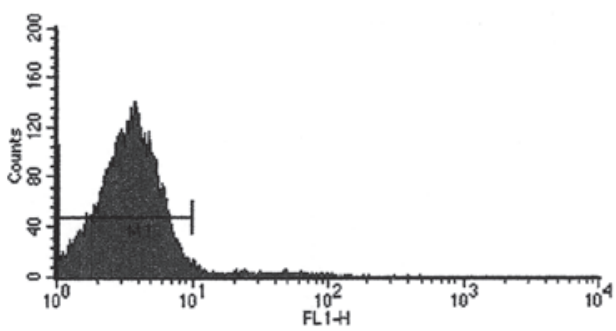

VIII

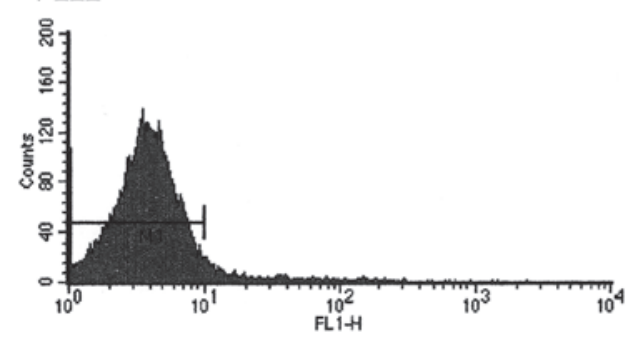

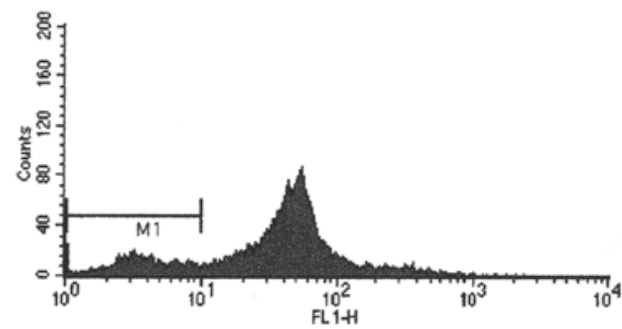
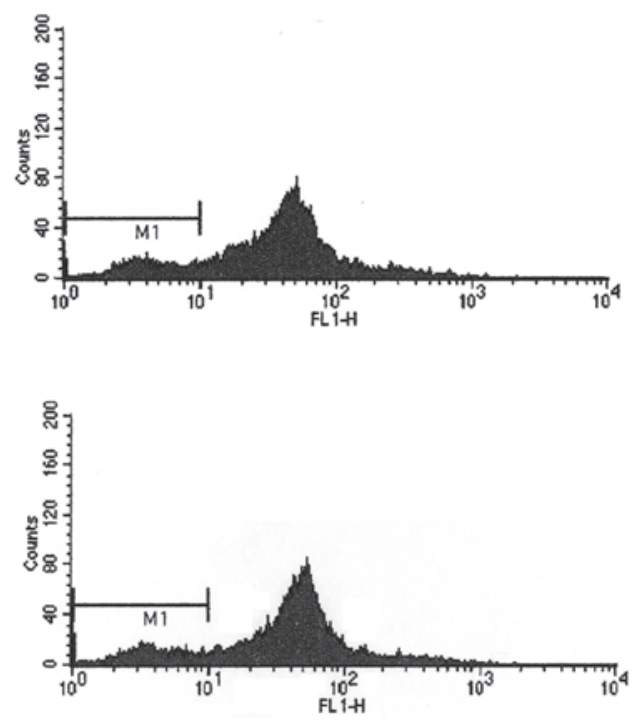

Figure 1. Identification of EPCs using flow cytometry. The graphs on the right were the control groups for the three markers, respectively. The graphs on the left-hand side represent the experimental groups. Flow cytometric analysis revealed that cells positively stained for EPC markers CD31, Flk-1, and factor VIII in $83.52,85.34$ and $83.86 \%$ of cells, respectively. EPC, endothelial progenitor cell, Flk-1, fetal liver kinase 1.

$83.52,85.34$ and $83.86 \%$ of cells, respectively (Fig. 1). Thus these cells were identified as EPCs.

Optical microscopy confirms the labeling efficiency of SPIO. Endocytosis of SPIO particles was observed in EPCs using optical microscopy. Following $6 \mathrm{~h}$ of incubation of EPCs with $35 \mu \mathrm{g} / \mathrm{ml}$ SPIO, characteristic granular SPIO particles were detected within the cytoplasm (Fig. 2). Following 24 h, the SPIO labeling efficiency increased to $100 \%$ in all groups and the endocytotic rate of SPIO particles positively correlated with the concentration of SPIO. However, no significant difference was found among the labeling efficiencies of the groups (Fig. 3). Furthermore, characteristic intracytoplasmic granular SPIO particles were observed following 28 days in culture (data not shown).

Cell growth and viability of EPCs labeled with different concentrations of SPIO. Fig. 4 shows the growth curve of EPC labeling with different concentration of SPIO $(17.5,35,70$ and $140 \mu \mathrm{g} / \mathrm{ml}$, respectively) following one week in culture. In groups 1, 2 and 3, the trends of cell growth were not significantly different to those of the control group ( $\mathrm{P}>0.05)$; in addition, MTT analysis of cell viability revealed no significant difference between the absorbance (490 nm) of groups 1, 2 and 3 compared with that of the control ( $\mathrm{P}>0.05)$ (Fig. 5). However, the cell growth and viability were markedly suppressed in the fourth group $(140 \mu \mathrm{g} / \mathrm{ml})$ as well as cell growth for group $3(70 \mu \mathrm{l} / \mathrm{mg})$.
Morphological changes of EPCs labeled with SPIO. Following one week in culture, electron microscopy revealed micorvilli on the surface of control cells as well as numerous intracellular organelles and prominent nuclear euchromatin with sharp nucleoli (Fig. 6A). EPCs labeled with SPIO at concentrations of $17.5 \mu \mathrm{g} / \mathrm{ml}$ and $35 \mu \mathrm{g} / \mathrm{ml}$ revealed identical characteristics, including figure, shape and nucleolus structure, compared to those of the control group (Fig. 6B and C). All concentrations of SPIO-labeled EPCs contained endolysosomal iron particles, whereas these were not observed in EPCs of the control group (Fig. 6B-D); in addition, EPCs labeled with $70 \mu \mathrm{g} / \mathrm{ml}$ SIPO exhibited an increased number of endolysosomes (Fig. 6E). However, EPCs labeled with $140 \mu \mathrm{g} / \mathrm{ml}$ SIPO underwent apoptotic cell death; morphologically, EPCs in this group demonstrated a reduced quantity of microvilli, a highly concentrated cytoplasm and the nucleus was located at the edge of the nuclear membrane (Fig. 6F). These results indicated that $35 \mu \mathrm{g} / \mathrm{ml}$ SPIO was a safe concentration for EPC-labeling, without affecting the biological characteristics of cells.

In vitro MRI. EPCs were labeled with $35 \mu \mathrm{g} / \mathrm{ml}$ SPIO and MRI was performed on different concentrations of SPIO-labeled cells (control, $1.0 \times 10^{4}, 5.0 \times 10^{4}, 1.0 \times 10^{5}$ and $5.0 \times 10^{5} / \mathrm{ml}$ ) in vitro (Fig. 7A). As shown in Fig. 7B, the T2WI signal intensity of SPIO-labeled EPCs decreased with increasing concentration of EPCs; in addition, $5 \times 10^{4} / \mathrm{ml}$ SPIO-labeled EPCs was the lowest concentration of cells observed within the imaging parameters. 


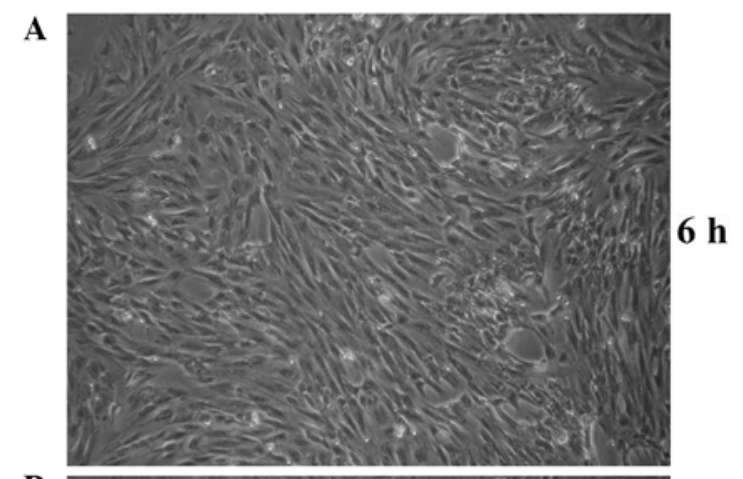

B

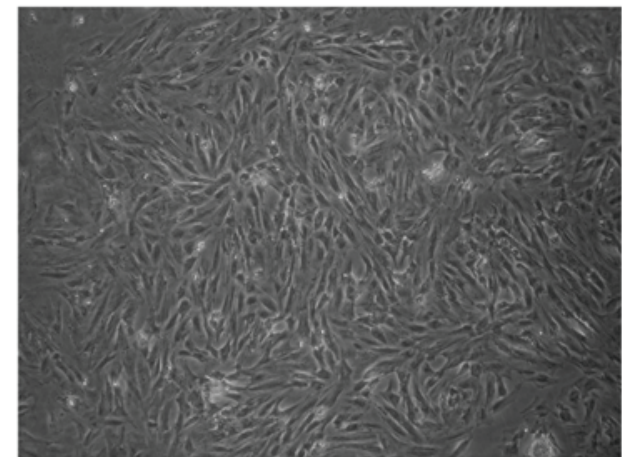

C

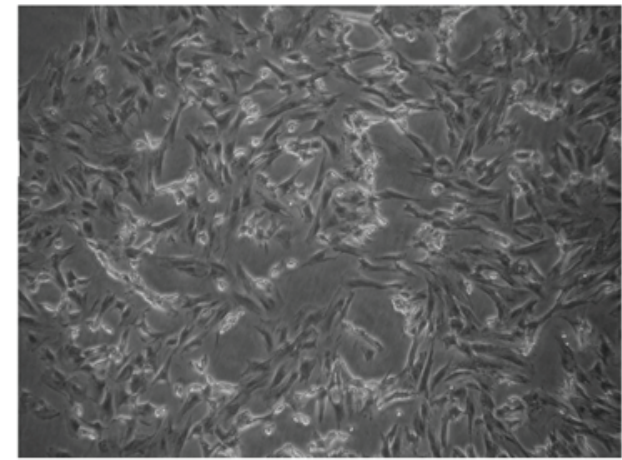

$12 \mathrm{~h}$

$24 \mathrm{~h}$

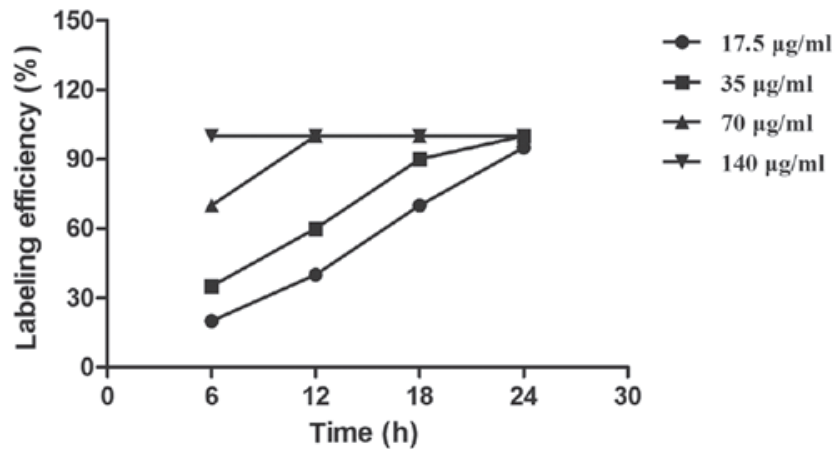

Figure 3. Labeling efficiency of EPCs labeled with SPIO. EPCs were incubated with different concentrations of SPIOs as follows: Group 1, $17.5 \mu \mathrm{g} / \mathrm{ml}$; group 2, $35 \mu \mathrm{g} / \mathrm{ml}$; group 3, $70 \mu \mathrm{g} / \mathrm{ml}$; and group 4, $140 \mu \mathrm{g} / \mathrm{ml}$. Labeling efficiency was the measured at different time-points. EPC, endothelial progenitor cells; SPIO, superparamagnetic iron oxide.

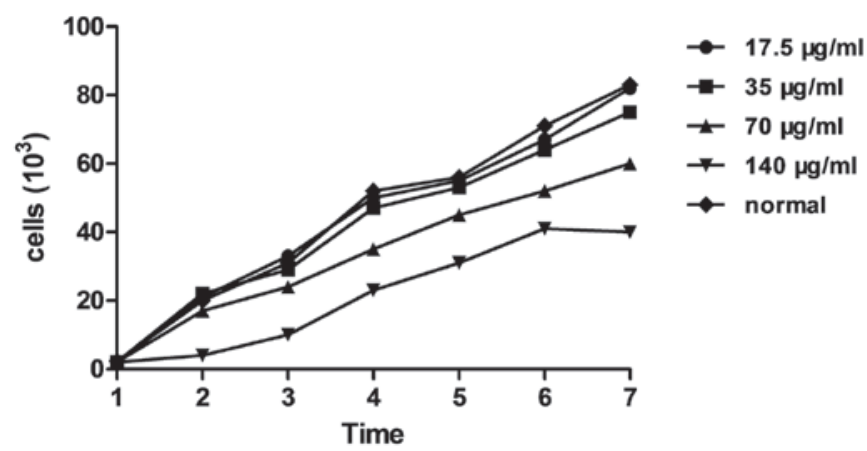

Figure 4. Cell growth curve of endothelial progenitor cells labeled with different concentrations of superparamagnetic iron oxide. Endothelial progenitor cells were incubated with different concentrations of superparamagnetic iron oxide as follows: Group 1, $17.5 \mu \mathrm{g} / \mathrm{ml}$; group 2, $35 \mu \mathrm{g} / \mathrm{ml}$; group 3, $70 \mu \mathrm{g} / \mathrm{ml}$; group 4, $140 \mu \mathrm{g} / \mathrm{ml}$; and an unlabeled control.

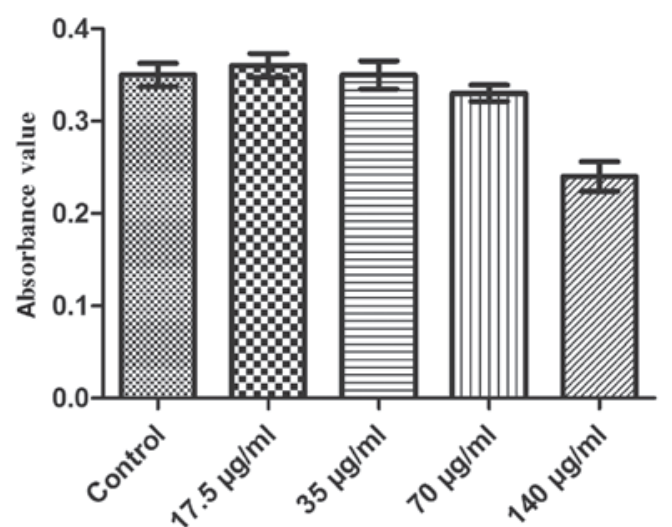

Figure 5. MTT assays were used to measure cell viability following labeling. Endothelial progenitor cells were incubated with different concentrations of superparamagnetic iron oxide as follows: Group 1, $17.5 \mu \mathrm{g} / \mathrm{ml}$; group 2, $35 \mu \mathrm{g} / \mathrm{ml}$; group 3, $70 \mu \mathrm{g} / \mathrm{ml}$; group 4, $140 \mu \mathrm{g} / \mathrm{ml}$; and an unlabeled control. Cells were then seeded into 96 -well microplates and cell viability was analyzed using an MTT assay.

Numerous studies have confirmed that EPCs may be used as an alternative cell-based approach for the enhancement of angio- and vasculogenic responses (25). Therefore, it was hypothesized that autograft EPCs may yield promising improvements in various animal models of ischemic disease. The MRI technique has numerous advantages, including a wide variety of imaging sequences, high resolution and improved soft-tissue contrast without radiation damage, which suggested its potential use for monitoring transplanted lyzed using an MTT assay.

cells (26). However, the traditional MRI was not able to differentiate the transplanted stem cells from the histiocytes; therefore, in order improve the contrast of the cells using MRI, the transplanted cells required modification. SPIO has been widely used as a negative marker to label cells $(27,28)$. In 
A

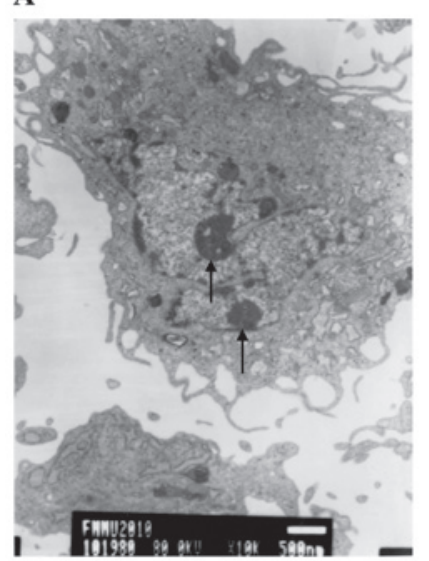

D

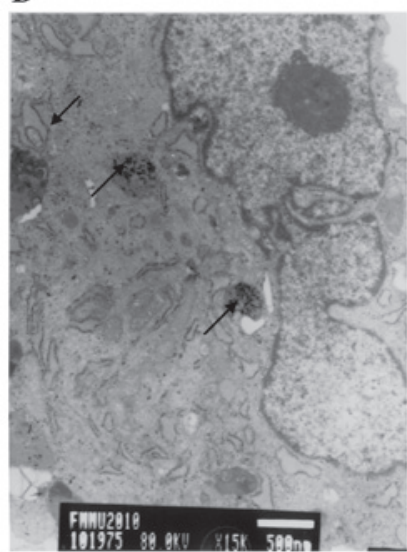

B

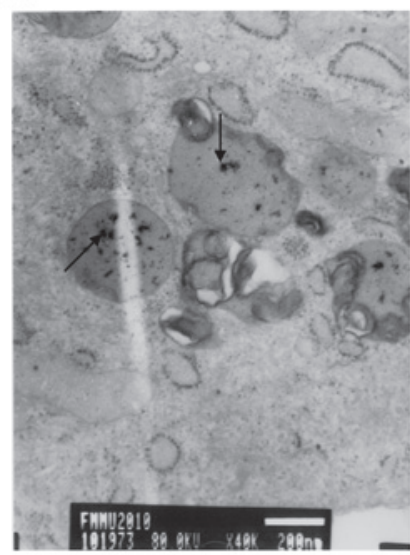

E

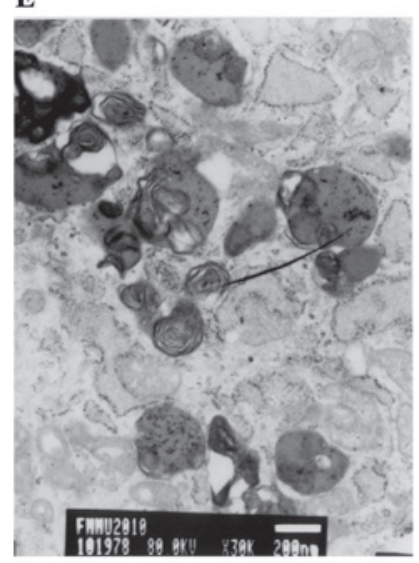

C

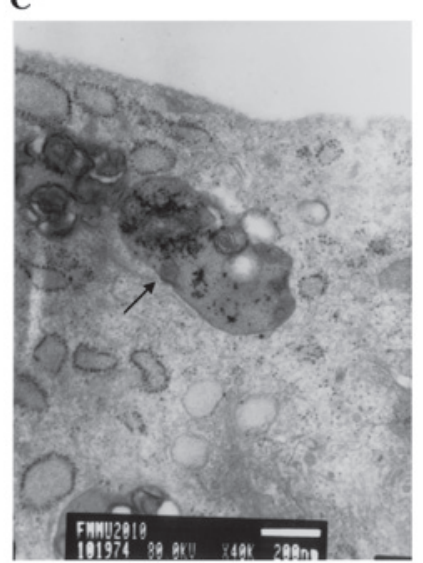

$\mathbf{F}$

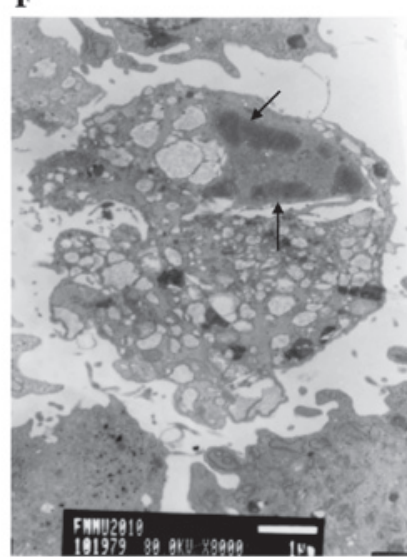

Figure 6. Electron micrographs of endothelial progenitor cells incubated with SPIO following one week in culture. (A) Unlabeled control cells with multiple microvilli, abundancy of organelles, and sharp nucleoli (black arrow). Black arrows represent iron particles in the lysosome of cells labeled with SPIO at concentrations of (B) $17.5 \mu \mathrm{g} / \mathrm{ml}$, (C) $35 \mu \mathrm{g} / \mathrm{ml}$ and (D) $70 \mu \mathrm{g} / \mathrm{ml}$. (E) Enhancement of lysosomes in cells labeled with $70 \mu \mathrm{g} / \mathrm{ml}$ SPIO. (F) Apoptotic cells following labeling with $140 \mu \mathrm{g} / \mathrm{ml}$ SPIO (black arrow). SPIO, superparamagnetic iron oxide.

A

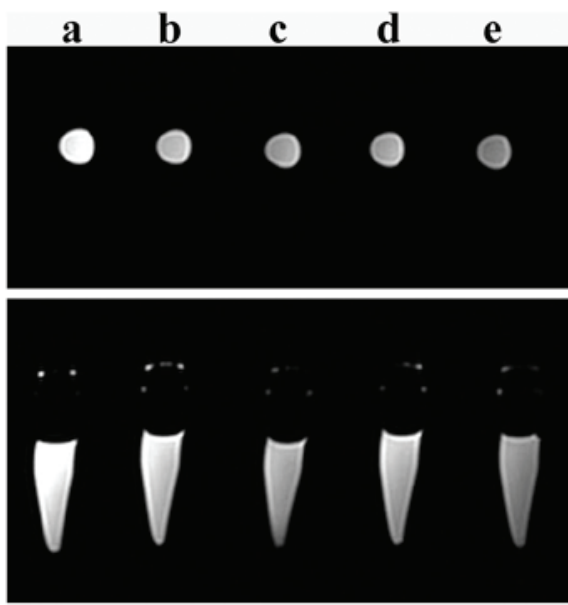

B

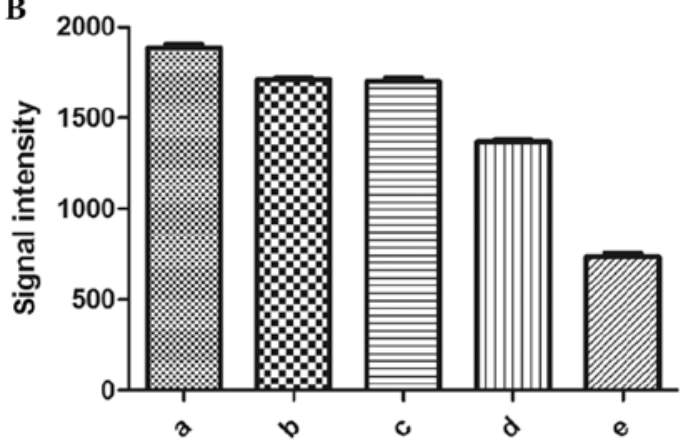

Figure 7. MRI of SPIO-labeled EPCs in vitro. (A) Different concentrations of EPCs were incubated with $35 \mu \mathrm{g} / \mathrm{ml}$ SPIO and then scanned using MRI in axial and sagittal planes. (B) Signal intensity differences of T2-weighted fast spin-echo in different groups were measured. The concentration of cells in groups were as follows: a, unlabeled control; b, $1 \times 10^{4} / \mathrm{ml} ; \mathrm{c}, 5 \times 10^{4} / \mathrm{ml} ; \mathrm{d}, 1 \times 10^{5} / \mathrm{ml}$; and e, $5 \times 10^{5} / \mathrm{ml}$. EPC, endothelial progenitor cell; SPIO, superparamagnetic iron oxide; MRI, magnetic resonance imaging.

order to accommodate the requirements of preoperative and intraoperative examinations using simple SPIO without additional indicators, the superior magnetic characteristics of SPIO required investigation to ensure its safety in vivo. In the present study, the reaction time, ratio and appropriate concentrations of SPIO and SPIO-labeled EPCs were calculated and analyzed. Previous studies confirmed that the absorption of iron particles had a positive correlation with cell number, SPIO concentration 
and the time of incubation (21). The results of the present study demonstrated that following $6 \mathrm{~h}$ of incubation with SPIO iron particles were phagocytized in all groups and labeling efficiency reached $100 \%$ in the group labeled with $140 \mu \mathrm{g} / \mathrm{ml} \mathrm{SPIO}$, while lower concentrations of SPIO reached $100 \%$ efficiency following $12,18-24$ and 30-36 h, respectively. This therefore indicated that the number of iron particles absorbed by EPCS increased with incubation time.

Arbab et al (29) and Himes et al (30) previously confirmed that the SPIO at concentrations $<50 \mu \mathrm{g} / \mathrm{ml}$ produced no side effects on cell activity. The results of the present study indicated that cell growth was unaffected by concentrations of SPIO $<70 \mu \mathrm{g} / \mathrm{ml}$; however, in EPCs labeled with $70 \mu \mathrm{g} / \mathrm{ml}$ SPIO, lysosome enhancement was observed and concentrations of SPIO $>70 \mu \mathrm{g} / \mathrm{ml}$ suppressed the biological activity of the cells. These results therefore indicated that it was safe to label EPCs with SPIO at concentrations of 20-70 $\mu \mathrm{g} / \mathrm{ml}$. In addition, the reaction time of cells was elongated at concentrations of SPIO $<20 \mu \mathrm{g} / \mathrm{ml}$; therefore, $35 \mu \mathrm{g} / \mathrm{ml}$ SPIO was selected to label target EPCs for subsequent experiments.

Due to the paramagnetism of SPIO, the T2WI signal significantly decreased during MRI, which was consistent with the effects of the negative contrast agent. As the cell number increased, the contrast effect was enhanced, which was thought to be due to the increased number of cells available to absorb the iron particles. In vitro MRI demonstrated that $5 \times 10^{4} / \mathrm{ml}$ was the lowest observable concentration of SPIO-labeled EPCs.

In conclusion, the results of the present study indicated that MRI was able to reflect changes in concentrations of intracellular iron and therefore has the potential for use in studying changes in SPIO-labeled EPCs in vivo for the treatment of myocardial infarction. However, further studies are required in order to determine the effect of SPIO-labeling of EPCs in vivo.

\section{Acknowledgements}

The present study was supported by grants from the National Science Foundation (nos. 81201135 and 30370821 ).

\section{References}

1. Asahara T, Murohara T, Sullivan A, et al: Isolation of putative progenitor endothelial cells for angiogenesis. Science 275 964-967, 1997.

2. Ribatti D: The involvement of endothelial progenitor cells in tumor angiogenesis. J Cell Mol Med 8: 294-300, 2004.

3. Murasawa $\mathrm{S}$ and Asahara T: Endothelial progenitor cells for vasculogenesis. Physiology (Bethesda) 20: 36-42, 2005.

4. Schmidt-Lucke C, Rössing L, Fichtlscherer S, et al: Reduced number of circulating endothelial progenitor cells predicts future cardiovascular events: proof of concept for the clinical importance of endogenous vascular repair. Circulation 111: 2981-2987, 2005.

5. Losordo DW and Dimmeler S: Therapeutic angiogenesis and vasculogenesis for ischemic disease: part II: cell-based therapies. Circulation 109: 2692-2697, 2004.

6. Tongers J, Roncalli JG and Losordo DW: Role of endothelial progenitor cells during ischemia-induced vasculogenesis and collateral formation. Microvasc Res 79: 200-206, 2010.

7. Kawamoto A, Katayama M, Handa N, et al: Intramuscular transplantation of G-CSF-mobilized CD34(+) cells in patients with critical limb ischemia: a phase IIIa, multicenter, single-blinded, dose-escalation clinical trial. Stem Cells 27: 2857-2864, 2009.
8. Cho SW, Moon SH, Lee SH, et al: Improvement of postnatal neovascularization by human embryonic stem cell derived endothelial-like cell transplantation in a mouse model of hindlimb ischemia. Circulation 116: 2409-2419, 2007.

9. Losordo DW, Schatz RA, White CJ, et al: Intramyocardial transplantation of autologous CD34+ stem cells for intractable angina: a phase IIIa double-blind, randomized controlled trial. Circulation 115: 3165-3172, 2007.

10. Thal MA, Krishnamurthy P, Mackie AR, et al: Enhanced angiogenic and cardiomyocyte differentiation capacity of epigenetically reprogrammed mouse and human endothelial progenitor cells augments their efficacy for ischemic myocardial repair. Circ Res 111: 180-190, 2012.

11. Giannoni E, Taddei ML, Parri M, et al: EphA2-mediated mesenchymal-amoeboid transition induced by endothelial progenitor cells enhances metastatic spread due to cancer-associated fibroblasts. J Mol Med (Berl) 91: 103-115, 2013.

12. Yin M, Liao Z, Yuan X, et al: Polymorphisms of the vascular endothelial growth factor gene and severe radiation pneumonitis in non-small cell lung cancer patients treated with definitive radiotherapy. Cancer Sci 103: 945-950, 2012.

13. Liu Y, Xia T, Zhang W et al: Variations of circulating endothelial progenitor cells and transforming growth factor-beta-1 (TGF- $\beta 1$ ) during thoracic radiotherapy are predictive for radiation pneumonitis. Radiat Oncol 8: 189, 2013.

14. Yang SY, Sun JS, Liu CH, et al: Ex vivo magnetofection with magnetic nanoparticles: a novel platform for nonviral tissue engineering. Artif Organs 32: 195-204, 2008.

15. Wu CC, Lin LY, Lin LC, et al: Bio-functionalized magnetic nanoparticles for in vitro labeling and in vivo locating specific biomolecules. Appl Phys Lett 92: 142504, 2008.

16. Oghabian MA, Gharehaghaji N, Amirmohseni S, et al: Detection sensitivity of lymph nodes of various sizes using USPIO nanoparticles in magnetic resonance imaging. Nanomedicine 6: 496-499, 2010

17. Müller S: Magnetic fluid hyperthermia therapy for malignant brain tumors - an ethical discussion. Nanomedicine 5: 387-393, 2009.

18. Gazeau F and Wilhelm C: Magentic labeling, imaging and manipulation of endothelial progenitor cells using iron oxide nanoparticles. Future Med Chem 2: 397-408, 2010.

19. Cheng K, Wei MQ, Jia GL, et al: Effects of metoprolol and small intestine RNA on marrow-derived endothelial progenitor cells applied for autograft transplantation in heart disease. Eur Rev Med Pharmacol Sci 18: 1666-1673, 2014.

20. Cho SW, Moon SH, Lee SH, et al: Improvement of postnatal neovascularization by human embryonic stem cell derived endothelial like cell transplantation in a mouse model of hind limb ischemia. Circulation 116: 2409-2419, 2007.

21. Gill M, Dias S, Hattori K, et al: Vascular trauma induces rapid but transient mobilization of VEGFR2(+)AC133(+) endothelial precursor cells. Circ Res 88: 167-174, 2001.

22. Gehling UM, Ergün S, Schumacher U, et al: In vitro differentiation of endothelial cells from AC133-positive progenitor cells. Blood 95: 3106-3112, 2000.

23. Peichev M, Naiyer AJ, Pereira D, et al: Expression of VEGFR-2 and AC133 by circulating human CD34(+) cells identifies a population of functional endothelial precursors. Blood 95: 952-958, 2002.

24. Moon SH, Kim SM, Park SJ, et al: Development of a xeno-free autologous culture system for endothelial progenitor cells derived from human umbilical cord blood. PLoS One 8: e75224, 2013.

25. Rosell A, Morancho A, Navarro-Sobrino M, et al: Factors secreted by endothelial progenitor cells enhance neurorepair responses after cerebral ischemia in mice. PLoS One 8: e73244, 2013.

26. Sun JH, Zhang YL, Nie CH, et al: In vitro labeling of endothelial progenitor cells isolated from peripheral blood with superparamagnetic iron oxide nanoparticles. Mol Med Rep 6: 282-286, 2012.

27. Zhang B, Li Q, Yin P, et al: Ultrasound-triggered BSA/SPION hybrid nanoclusters for liver-specific magnetic resonance imaging. ACS Appl Mater Interfaces 4: 6479-6486, 2012.

28. Yoo MK, Park IK,Lim HT, et al: Folate-PEG-superparamagnetic iron oxide nanoparticles for lung cancer imaging. Acta Biomater 8: 3005-3013, 2012.

29. Arbab AS, Bashaw LA, Miller BR, et al: Intracytoplasmic tagging of cells with ferumoxides and transfection agent for cellular magnetic resonance imaging after cell transplantation: methods and techniques. Transplantation 76: 1123-1130, 2003.

30. Himes N, Min JY, Lee R, et al: In vivo MRI of embryonic stem cells in a mouse model of myocardial infarction. Magn Reson Med 52: 1214-1219, 2004. 